\title{
The Dynamics of Paradiplomacy Practices in the "Frontier" Areas in Indonesia
}

\author{
Ali Maksum \\ Surwandono
}

\author{
Universitas Muhammadiyah Yogyakarta \\ Universitas Muhammadiyah Yogyakarta
}

\begin{abstract}
Paradiplomacy has been commonly conducted by local governments in Indonesia since the collapse of the centralized New Order regime. Decentralization as one of the post New Order political reform demands local government to be more active in managing their own region. The vast opportunity to boost international partner under this new system has paved the way to the practice of paradiplomacy including that in the frontier areas in Indonesia. This qualitative research aims to understand paradiplomacy practices notably in the frontier areas in Indonesia that are characteristically vulnerable to separatism. Using discourse analysis, this research focuses on two important areas in the frontier Indonesia namely, Riau Island and West Kalimantan. This research found that "ceremonial" paradiplomacy has been blatantly practiced amid of the tighten and bureaucratic barrier including obstacles on the budget implementation.
\end{abstract}

Key words: paradiplomacy, investment, central government, local government, authority

\section{Introduction}

Issues in international relations have shifted from the previously dominating high political issues centred on the question of war and peace to bigger proportion of low political issues such as economic cooperation and identity. In this context, a comprehensive strategy is needed to defend national interests.

Effective communication is one of the main factors during negotiations which is often referred to as diplomacy. George Kennan defines diplomacy as "an art and international manifestation in a universal context". Nicolson clarifies the definition of diplomacy to include "(a) The internal management of negotiation, (b) The method is adjusted and managed by ambassadors and envoys, (c) The business diplomats, and (d) Skill or address in the conduct of international intercourse and negotiation. Diplomacy is in short could be defined as a way of communication with the selection of words and sentences carried out by various parties including negotiation between acknowledged representatives to achieve state's interests. Thus, diplomacy is a state effort through a good way of communicating with elected representatives to reach national interests in a peaceful manner (Fathun, 2016, p. 76). 
There are three paradigms of diplomacy. Firstly, trans-border paradiplomacy, which refers to institutional, formal and informal relations by different sub-national governments but directly borders geographically. Second, transregional paradiplomacy, which refers to diplomatic relations carried out by different subnational governments who do not have direct borders, but still located in one region. The third type is global paradiplomacy, which refers to relations by sub-national governments from different regions, from various parts of the world. These three forms of diplomacy are very likely to develop and contribute to the performance of the country's diplomacy as a whole (Damayanti, 2012, p. 2).

However, this only occurs if paradiplomacy is managed properly by the central government. Yet, along with the increasingly blurring boundaries between regional and global issues, domestic and international issues, while international relations is more accessible to sub-state actors, it is not impossible that foreign relation activities by sub-national actors develop toward proto-diplomacy, that is diplomacy by sub-national government that leads to the search for support for separatist activities. (Damayanti, 2012, p. 4).

Since the collapse of Suharto regime in 1998 followed by political transformation in Indonesia, paradiplomacy became a new model for local government to boost economy through international network. This is because of the drastic changes in Indonesian government notably on the local and central government relations that will be elaborated more in the next section. Further, local government has been given more power and authority to manage assets and resources including in the frontier areas. Riau Island and West Kalimantan are the two critical frontiers areas for Indonesia since both provinces directly have land and sea borders with neighbouring countries. Therefore, this is important to examine how the practice of paradiplomacy in both provinces that geographically attractive for investment and international trade. The situation is also challenging to both provinces amid of the high demand on clean, transparency, and good governance.

The objective of this article is thus 1) to examine paradiplomacy practices in Riau Island and West Kalimantan in general, and 2) to examine the local government response on paradiplomacy vis-à-vis central government and the new regulations in the post-decentralisation amid of the ceremonial and formality cultures inside the local governments.

\section{Methodology}

This study a is qualitative research using content analysis. This research attempts to offer analysis based on secondary data from the provided documents such as government reports, press release, media coverage, books and journals. The authors also have worked through specific regulations pertaining 
paradiplomacy and local government laws in both provinces such as:

1. Indonesian Law no. 22/1999 on Regional Autonomy.

2. Indonesian Law no. 32/2004 on Local Government.

3. Indonesian Law no. 33/2004 on Fiscal Balance between Local and Central Governments.

4. Indonesian Law no. 23/2014 on Local Government (amended of Indonesian Law no.32/2004).

5. Government Regulation No.46 / 2007 for Batam KPBPB (Kawasan Perdagangan Bebas dan Pelabuhan Bebas).

6. Government Law no.47/2007 for Bintan KPBPB.

7. Government Law no.48/2007 for Karimun KРBPB.

8. Indonesia-Malaysia agreement on cross-border trade on 24 August 1970.

9. Indonesia-Malaysia agreement on cross-border activities on 12 May 1984.

10. Indonesian Law no. 10/1995 on Customs.

11. Ministry of Trade Decree no. 36/KP/III/1995 on cross-border trade through cross-border security checkpoint in Entikong (PPLB, pos pemeriksaan lintas batas) in West Kalimantan.

12. Ministry of Finance Decree no. 490/KMK 0.5/1996 on management of import, passengers, carrier crew, cross-borders, and shipping.

13. Directorate General of Custom Decree no. KEP-78/BC/1997 on manual guide for luggage of passengers for carrier crew, crossborders, and shipping.

Meanwhile, both provinces namely Riau Island and West Kalimantan were selected due to the strategic location of the provinces. Compared to other regions in the frontier areas in Indonesia, Riau Island and West Kalimantan have at least two critical aspects. First, both provinces are strategically important for national security since they have direct land and seas borders. Riau Provinces for instance has direct borders with Singapore, Malaysia, Thailand, and Vietnam as well as with the "hot spot area" of the South China Sea. At the same time, West Kalimantan also has land and sea borders directly with Malaysian state of Sarawak. Second, Riau Island and West Kalimantan are economically located in the most growing economy in the world involving countries namely Singapore, Malaysia and Thailand (Ngoc, 2015; Litsareva, 2017).

\section{Paradiplomacy and Ceremonial Paradiplomacy}

Paradiplomacy is the diplomacy conducted by sub-national, regional, or local institutions (not the central government) for their interests. Local government has the opportunity to promote trade, investment, and various potential cooperation with parties that previously dominated by state's jurisdiction. Paradiplomacy that has been commonly implemented by regional governments in Indonesia includes sister city, investment, joint projects, and staff exchange. 
The 'paradiplomacy' phenomenon actually emerged in Europe, but currently it has become a common symptom in the midst of transnational interactions of the world community, including in Indonesia. Many autonomous regions or provincial/ regency/ municipal governments actively engage in foreign cooperation with foreign parties in the form of 'memorandum of understanding' or other forms of international agreements. The strongest motivation behind the emergence of regional desire to carry out diplomacy activities is economic factors. The aim of the region to carry out the diplomacy in this case is to attract foreign investment, attract multinational companies to its territory, and target new export markets. Its function is solely to compete at the global level, so that it has no political factors at all. Among issues that must be observed in the implementation of this paradigm in Indonesia is whether state regulation has covered this practice comprehensively, how foreign cooperation by the autonomous region be developed to national level, and how the integration gaps can be carefully anticipated (Mukti, 2015, p. 86).

Paradiplomacy must be carefully used as it is different from the other concept known as ceremonial paradiplomacy. According to Tavares (2016), it is related to the paradigm of formalities developed especially among Asian countries with nascent democracy. In this case, ceremonial paradiplomacy is conducted in response to the demands for the implementation of paradiplomacy promoted by the central government. Thus, various collaborations that have been established are nothing more than ceremonial and formality in order to fulfil performance as a government.

In Indonesia, ceremonial politics has become a common activity in various government agencies. Generally, this is also influenced by the increasingly rampant culture of political formalities after 1998 political reform. Politics of formalities usually carried out as a form of accountability for government programs to the public (Tobirin, 2013). In addition, the public knows the performance of the government even though it is only ceremonial.

\section{Paradiplomacy in Indonesian Law}

Historically, before the enactment of Law Number 32/2004, the authority for local government to conduct international cooperation had begun since the enactment of the Law on Regional Government in 1999, better known as Undang-Undang Otonomi Daerah (Regional Autonomy Law). In the context of Law No. 22/1999, the authority to enter into foreign cooperation is included in the category of authority that is not obligatory for the regions. Article 88, paragraph (1) declares that "Regions can establish mutually beneficial cooperation with institutions/agencies abroad, which are governed by joint decisions, except those concerning the authority of the Government, as stipulated in Article 7".

In Law No. 32/2004, the authority of the autonomous region to carry out 
foreign cooperation is reinfornced as provided in article 42 paragraph 1 mentioned that Dewan Perwakilan Rakyat Daerah (DPRD or local house) has the duty and authority to give approval to plan for international cooperation carried out by local government. Further, in the context of sister city/province, local government could also make technical cooperation agreements including humanitarian assistance, cooperation in loans/grants, cooperation in capital participation and other cooperation in accordance with the laws and regulations (Mukti, 2013, pp. 3$4)$.

There have been experiences where bureaucrats in the provincial, regency and city administrations which previously had almost never been in touch with foreign diplomacy between nations experience many difficulties both related to diplomatic skills and practical experience in dealing with foreign parties. This is so as implementing paradiplomacy requires sufficient capacity such as mastery of laws and codes of ethics for relations between nations. Lacking these skills will influence the quality of the product of cooperation with various foreign parties, and thus it is not optimal in pushing the pace of regional development, or perhaps it will be counterproductive as it will only waste regional budget or Anggaran Pendapatan dan Belanja Daerah (APBD, local government budget) because officials often travel overseas.

In this context, DPRD's oversight on the implementation of international cooperation is very important because the emergence of new authority for autonomous regions will automatically have an impact on regional budgeting. This supervision is important not only to prevent the emergence of wasteful regional budgets, but also to keep foreign parties from complying with the agreements (Mukti, 2013, pp. 6-7).

\section{Paradiplomacy in Riau Island}

In the context of Riau Islands, the discussion of paradiplomacy is related to what is referred to as free trade and free ports (KPBPB, Kawasan Perdagangan Bebas dan Pelabuhan Bebas). KPBPB Batam, Bintan, Karimun is located on an international shipping crossing of the Malacca Strait. This area is directly on the opposite of the neighbouring Singapore and Malaysia (South Johor). Domestically, it is adjacent to the City of Pekanbaru and passed by the PELNI line.

KPBPB Batam, Bintan, Karimun is administratively managed under the Riau Islands Province, together with Batam City, Bintan Regency, Tanjung Pinang City and Karimun Regency. However, not all of these administrative areas are designated as KPBPB. In the national context, KPBPB Batam, Bintan, Karimun (BBK) is one of the National Strategic Areas (KSN) and Special Economic Zone (KEK).

Regarding the development of this region, it was initially emerged from an economic cooperation agreement between the Government of Indonesia and Singapore. The cooperation agreement 
was then followed up with the establishment of KPBPB development locations through Government Regulation No.46 / 2007 for Batam KPBPB, PP No.47 / 2007 for Bintan KPBPB and PP No.48 / 2007 for Karimun KPBPB. In its operationalization, Presidential Regulation No. 9, 10, and 11 of 2008 was issued to provide legal institutional framework for KPBPB Batam, Bintan, Karimun Zone Council.

The idea of developing KРBPB BBK as Special Economic Zones was originally modelled after the establishment of special economic zones carried out by China which divide a region itu economic, trade and tourism areas. Therefore, in the areas of BBK, the implementation of special economic zones is also divided into several special zones as follows:

1. Special Trade Zone in Lagoi Bintan

2. Special Industrial Zone at the Lobam Batam

3. Special Mining Zone (Special Mining Zone) in Bintan and Karimun. (Indra Pahlawan, 2014, pp. 2-3).

In executing this idea, the Government of Indonesia has cooperated with the Government of Singapore. This cooperation has been formulated in a draft collaboration between Indonesia and Singapore on June 25, 2006. President Susilo Bambang Yudhoyono from Indonesia and Prime Minister Lee Hsien Loong from Singapore witnessed the signing of the economic MoU for the BBK region.
The SEZ agreement itself was signed by Coordinating Minister for Economy - Boediono and Singapore Minister of Trade \& Industry - Lim Hing Kiang in Nongsa Point Marina Batam. A Joint Steering Committee was formed to follow up this agreement. The Committee was chaired by Indonesian Coordinating Minister for Economic Affairs Boediono and Singapore's Economy Minister Lim Hing Kiang. The implementation of the special economic zone itself was carried out by a Joint Working Committee chaired by the Indonesian Minister of Trade Maria Elka Pangestu and Chair of Singapore Economic Development Mr. Lim Siong Guan. Within the deadline of four months, the Committee must have inventoried the problems faced by entrepreneurs from the two countries and the results were reported to Indonesian President and Singapore Prime Minister.

If we look at the investment side up to 2014, the total amount of all investments was US \$ 27.7 billion with the ratio of investment from private sector and from the government amounting to $79.73 \%$ compared to $20.27 \%$ respectively. However, one of the main objective of the SEZ is to attract foreign investment (FDI). From the development of economic cooperation between Indonesia and Singapore in the formation and development of SEZ in 2009, the effort to attract foreign direct investment (FDI) was not optimal. This is proven from domestic private investment that is greater or more dominant than foreign investment, that is, $52.42 \%$ compared to $47.58 \%$ respectively. An SEZ development can be said to be 
more successful if foreign investment is 79.73\% (Arjuna, 2016, p. 7).

In 2016, the realisation of Foreign Investment (PMA) in Batam City amounted to $\operatorname{Rp} 6.26$ trillion (71 Projects), an increase of $46.6 \%$ compared to the previous period in 2015 which only reached $\mathrm{Rp} 4.27$ trillion (63 Projects). The realisation of this FDI is generally dominated by transportation and other transportation industry sectors, as well as non-metallic mineral industry and basic chemical industry.

The realisation of Domestic Investment (PMDN) in 2016, however, amounted to $\operatorname{Rp} 489.5$ billion (75 projects), which means a significant increase of 13 times from 2015 of Rp 34.7 billion (77 projects). This increase was contributed by the increase in investment projects in oil and natural gas mining and property projects in Batam City in 2016 (BKPM, 2017).

It was only in 2017 that the trend has changed. According to the Head of Licensing Division of the One-Stop Integrated Investment and Services Agency (BPMPTSP), throughout 2017, the total investment value entering the Bintan Regency, Riau Islands, reached IDR 14 trillion. "A total of 27 foreign investment companies (PMA) have invested as much as USD 921 million or equivalent to IDR 12.3 trillion. Meanwhile, the type of Domestic Investment (PMDN) there were eight companies with investment value reaching $\quad$ Rp1.7 trillion. Foreign investment in this year surpassed the domestic investment.
Among foreign companies investing in this region were Gallant Venture group from Singapore focusing on hospitality and resort tourism, namely PT Gallant Lagoi Phenomenon of USD 20 million, PT Gallant Lagoi Inti USD 18 million, PT Gallant Lagoi Abadi USD 16 million, PT Gallant Lagoi Damai is USD 26 million, and PT Gallant Lagoi Jaya is USD 22 million. Other companies include PT Gallant Lagoi Gemilang, PT Gallant Lagoi Harmoni, PT Gallant Lagoi Elok, PT Lagoi Berjaya, PT Gallant Lagoi Cemerlang, PT Gallant Onbase Resort, and several other foreign companies. Meanwhile, for investments from national companies include Melia Bintan Hotel with investment value as much as IDR 500 billion, and several other companies (Rofik, 2018).

Nevertheless, this study found that even though paradiplomacy has been carried out in the free trade area especially in Batam, Bintan, Karimun, the official MoU between local governments with foreign companies was rare. This is due to the existence of two authoritative agencies namely Batam Indonesia Free Zone Authority (BIFZA, Badan Pengusahaan Batam) and Batam City Government.

In addition, there is still lack of trust and integration between both parties - BIFZA and Batam City Government due to miss-coordination among departments. In the context of paradiplomacy, Riau Island has got some achievements from investment sectors. Nonetheless, ceremonial paradiplomacy 
still exists since local government faces difficulties in budget expenditure.

The last mentioned has been particularly becoming a serious debate in the local house of representatives (DPRD) of Riau Island Province following the calculation of foreign visit budget. The local government expressed the disappointment on the policy. According to the house member, "it is better if the budget is used to maximize service performance to the people. For instance, one-way budget reaches Rp 900 million. This is very wasteful and not useful if you just spend only for overseas trip." $\mathrm{He}$ added that "hundreds of millions of moneys is also public money which will be more useful if it is used for the people" (Tanjung Pinang Pos, 2011).

The governor of Riau Island also received critics following his plan to visit Germany and the Netherland. His trip was expected to promote free trade zone in Riau Island, yet remain controversial among the people (Tribun Batam, 2012). This is a strong indication, how paradiplomacy still have obstacles especially among local apparatus. The "ceremonial" culture exists including that in Riau Island.

\section{Paradiplomacy in West Kalimantan}

Different from paradiplomacy in Riau Province, paradiplomacy in West Kalimantan relates to Mining investment in the region. In 2010-2015, major investment in West Kalimantan was in the field of non-ferrous metal (smelter) and downstream mining industries with a total of 15 projects consisting of 13 foreign investment projects. Investors in this region are from various countries such as Japan, Singapore, Malaysia, Hong Kong, the People's Republic of China (PRC) and the British Virgin Island (The Tanjungpura Times, 2016).

In 2016, West Kalimantan Province was ranked as the top 10 foreign investment location in Indonesia. It was ranked number 6 with investment value US \$ 1.2 billion, only one below East Kalimantan in number five with US \$ 1.3 billion foreign investments. All foreign investment targets in West Kalimantan in 2015 were well achieved. The biggest foreign investment in West Kalimantan comes from Japan, Singapore, Malaysia, Hong Kong, PRC (Tribun Pontianak, 2016).

The realisation of investment in West Kalimantan during 2017 also achieved impressive results with a value of Rp 19.96 trillion or exceeding the target set by West Kalimantan Provincial Government at Rp 18.61 trillion. This number include foreign direct investment as much as $\mathrm{Rp} 7.58$ trillion and domestic investment as much as $\operatorname{Rp} 12.38$ trillion. In additions, there are 413 additional projects from domestic investment and 838 reports from foreign investment. Of the 413 domestic investment project, food crops and plantation businesses are accounted for 135 project reports with an investment value of Rp.8.83 trillion. Meanwhile, 636 projects from the foreign investment are predominantly dominated by business sectors in food crops, 196 projects in 
plantations and 176 project in business fields. The combined value of these investment is Rp.5.59 trillion. Overall, West Kalimantan FDI is the 17th highest compared other regions in Indonesia (Viodeogo, 2018).

Following are some foreign investor companies in West Kalimantan:

\section{a. PT. Indonesia Chemical Alumina (ICA)}

PT. ICA was established on February 26, 2007 and its ownership is $80 \%$ of PT. ANTAM (Persero) Tbk and $20 \%$ of Showa Denko KK. Showa Denko $\mathrm{KK}$ is a foreign company from Japan that creates excellent individual products through interconnection of non-organic, aluminium and organic chemical technologies (Showa Denko, 2018).

PT. ICA is the pioneer of the Chemical Grade Alumina (CGA) industry in Indonesia and occupies the fifth position in the Asia Pacific region together with Japan, China, Australia and Korea in processing bauxite into CGA. PT ICA is a pioneer in fulfilling the requirements of the Indonesian Mining Law in terms of processing raw materials domestically. It will also be the driver for the development of competitiveness and added value of the alumina-based industry in Indonesia in the future.

The CGA generally refers to chemical products in the form of aluminium hydroxide and alumina which are used for various industrial applications except the aluminium industry. Aluminium hydroxide is a semi- finished product that can be used for water purification. While alumina can be used to produce electronic supporting components. Some products that use CGA include refractoriness (abrasive materials), abrasive, assembled products, Integrated Circuit (IC), and basic materials for LCD screens (PT. Indonesia Chemical Alumina, 2014).

In the case of PT ICA, the workflow begin with Tayan CGA factory as a foreign factory which produces more than 100 types of alumina hydrates and alumina products. To produce this product, the production process at Tayan will be carried out in a factory architecture based on "Process Bayer" technology owned by Showa Denko, Japan, which has more than 70 years of experience in operating the plant in Yokohama. Alumina processing is specifically done by grinding, mixing, processing, and many others. Products packaged in paper bags, jumbo bags, and bulk bags are stored in warehouses before being sent to the market. Product delivery will be carried out via barges from Tayan Port to Pontianak and continued loading to ships to be delivered to the destination.

PT. ICA in carrying out its production activities always applies the Safety-First principle contained in the Occupational Health Safety (K3) guideline and conducts supervision, monitoring and prevention of environmental impacts. PT. ICA gives high priority to community development programs to help improve the living standards of the surrounding community through several program 
areas such as Improving the Quality of Public Health and the Environment, Education, Economic Empowerment, Socio-Culture, and Strengthening Community \& Government Institutional Capacity. For PT. ICA, this program is an inseparable part in realizing the success of the company (Pontianak Post, 2016).

\section{b. PT. Well Harvest Winning Alumina Refinery (WHW AR)}

PT. WHW AR is a processing and refining company of bauxite into alumina that produces high-quality Smelter Grade Alumina (SGA) with levels $>98.6 \%$ in Kendawangan District, Ketapang Regency, West Kalimantan. WHW AR is the largest refining and processing company in Southeast Asia and Indonesia that will serve the needs of SGA in the domestic (Indonesian) market, China, India and the Middle East. PT WHW AR is a local and Chinese investment joint venture. Local investors by PT Cita Mineral Investindo Tbk (CITA) hold the $25 \%$ stake and the remainder is by China Hongqiao Limited Group (60\%), Winning Investment (HK) Company Limited (10\%), and PT Danpac Resources Kalbar (5\%) (Pontianak Post, 2016).

PT. WHW AR was established in 2012 and completed processing of plants and refining bauxite into phase I alumina with a production capacity of 1 million tons on May 21, 2016. The establishment of PT. WHW AR is intended to respond to the enactment of Law No. 4 of 2009 concerning minerals and coal and the Minister of Energy and Mineral Resources No. 7 of 2012. The two regulations encourage programs to increase the added value of mining products and the obligation to process and purify minerals within the country. The investment value of the construction of this plant is US\$ 1 billion (around $\mathrm{Rp} 9.8$ trillion) with a production capacity of 2 million tons of alumina per year. The realisation of the investment value was divided into two stages, namely in 2013 until the plant is established in 2015 with a capacity of 1 million tons of alumina. The other half is in 2016, when the factory has been operating for one year (PT. WHW AR, 2017).

In its investment activity, PT. WHW AR has cooperated with West Kalimantan provincial government. PT. WHW AR, for example, has helped accelerating regional economic growth which contributed to the opening of employment opportunities for local communities and thus, reduce unemployment and poverty.

In addition, the cooperation dictates that both parties can work together in maintaining the security of the West Kalimantan region, especially in Kendawangan, Ketapang district and in increasing the development of border areas and infrastructure facilities (West Kalimantan Provincial Government, 2016). In the pre-reconstruction period, there were 125 workers who joined the management training program in China, specifically for learning about technology (Tribun Ketapang, 2017). Other cooperation carried out by PT. WHW AR with the government is in the national 
aluminium industry sector. PT WHW AR is a bauxite processing plant and is becoming the first alumina company in Indonesia and Southeast Asia.

\section{c. Jembatan Pak Kasih Tayan}

Pak Kasih Tayan Bridge is the southern axis that connects between West Kalimantan and Central Kalimantan. This river crosses over the Kapuas River, Sanggau Regency and is the longest bridge in Kalimantan and number two in Indonesia. The tomb of the Pak Tayan pack has an overall length of 1,440 meters and a width of 11 meters. The bridge was built in 2011 and finished in February 2016 and was inaugurated by President Joko Widodo on March 22, 2016. The Pak Kasih Tayan Bridge Project spent a total cost of $\mathrm{Rp} 1.038$ trillion with Chinese loans of 90\% and State Budget $10 \%$. This bridge was built in collaboration with the Chinese government (Road and Bridge Corporation) and PT. Wijaya Karta Tbk, Indonesia (Tribun Ketapang, 2017).

Behind its main function as a connecting hub for Kalimantan (West Kalimantan, Central Kalimantan and East Kalimantan and South Kalimantan) which is cut off by the Kapuas River in Tayan Hilir, the Pak Kasih Tayan Bridge will also become a new tourist attraction for Sanggau Regency, West Kalimantan. In addition, the ornaments and panoramas of the Kapuas river are attractive for tourists. The Pak Kasih Tayan Bridge is also the longest bridge in Kalimantan. The bridge has two main spans, the first is 430 meters long and the second is 1,330 meters and is $112 \mathrm{~km}$ from Pontianak, the provincial capital of West Kalimantan (Detiktravel.com, 2016).

\section{d. PT Wilmar International Limited}

Wilmar international limited was founded in 1991 and headquartered in Singapore. PT. Wilmar International Limited is a leading agribusiness company in Asia. Wilmar is ranked among the largest companies listed based on market capitalization on the Singapore stock exchange. Wilmar's business activities include palm plantations, oil seed extraction, vegetable oil refining, sugar milling and refining, consumer product manufacturing, oleo chemical specialty fats, biodiesel and fertilizers and flour and rice mills. The core of Wilmar's strategy is an integrated agribusiness model that covers the entire value chain of agricultural commodity businesses, starting from the cultivation, processing, manufacturing, to selling various kinds of agricultural products. Wilmar has more than 500 factories and extensive distribution networks such as China, India, Indonesia and around 40 other countries. PT. Wilmar International Limited has a multinational workforce of around 90,000 people (PT. Wilmar International Limited, 2018).

In West Kalimantan there are seven foreign investments that invest their capital in oil palm plantations, while domestic investment has only six companies. The area of oil palm plantations in West Kalimantan as of October 2009 was 499,548 hectares, still far from the target of 1.5 million heirs. While data from Sawit Watch a local NGO 
mentioned of 50 of oil palm plantation companies or 7.8 million hectares is foreign-owned property. Among them are entrepreneurs from Malaysia, Singapore, US, UK, and Belgium. This occurred due to "political game" at the local decisionmaking level concerning to business permission. Overall, oil palm plantations are controlled by 30 groups and around 700 subsidiaries. In just five years from 1999 to 2004 the rate of planting of oil palm plantations reached 400 thousand hectares per year. Director general of plantations, Ministry of Industry of Indonesia, Achmad Manggabarani said Indonesia remained focused on efforts to achieve the target of producing 40 million tons of crude palm oil (CPO) by 2020 (Ministry of Industry, 2016).

\section{Foreign Cooperation of West Kalimantan}

\section{a. Socio-economic cooperation on Socio Economic between West Kalimantan-Sarawak State}

The Malaysia-Indonesia (Malindo) Socio-Economic Cooperation between Government of West Kalimantan and Sarawak's Domestic Affairs has actually been established for a long time. The forms of cooperation based on the result of the meeting are:

1) Strengthening $\mathrm{HR}$ capacity at the border

2) Increased access and security

3) Building interconnection and interinstitutional operability

4) Strengthening border HDI
5) Building a pattern of border management and land and maritime borders

6) Environmental management and border SDA

Source: (Arindapraja, 2015).

The committee's tasks are as follows:

1. To determine socio-economic development projects.

2. To supervise the implementation of socio-economic development and border areas.

3. To carry out information exchange regarding socio-economic development in the joint border region.

Source: (Arindapraja, 2015).

\section{b. Cooperation on Interconnected- Electricity between West Kalimantan-Sarawak State}

Electricity interconnection cooperation projects between State of Sarawak and West Kalimantan have completed. The $275 \mathrm{kV}$ transmissions between the two regions on the IndonesiaMalaysia border have even been synchronized since January 20, 2016 (Secretariat of Riau Province, 2017). The development of the US \$ 118 billion project was also discussed in a bilateral meeting between the Minister of Energy and Mineral Resources Dr. Sudirman Said and Malaysian Minister of Energy, Green and Water Technology (TTHA), Datuk Seri Dr. Maximus Ongkili, in Kuala Lumpur on January 2016.

Based on the electricity cooperation under the ASEAN Power 
Grid, the Indonesian National Electricity Company (PLN) will import $50 \mathrm{MW}$ of electricity after the peak load time (LWBP) and a maximum of $230 \mathrm{MW}$ during peak load time (WBP) with free of charge. Furthermore, this electricity exchange will be carried out according to the commercial scheme. This cooperation is still within the framework of the ASEAN Power Grid, specifically the joint project of the PLN and SESCO Malaysia to connect seabed cables between Riau and Malaka. Another collaborative project that is still ongoing is the Sabah-North Kalimantan project (Harefa \& Badaruddin, 2016; Sinambela, 2017).

This cooperation also refers to the agreement in Power Exchange Agreement (PEA) in which PLN Indonesia and SESCO Malaysia agreed to buy and sell (export-import) electricity for 25 years. In addition, in this PEA agreement, PLN builds a $275 \mathrm{kV}$ extra high voltage transmission (EHVT) and $282 \mathrm{~km}$ circuits from extra high voltage sub-station of Bengkayang to the border in Serikin, in State of Serawak, so that the total length of (EHVT) is $127 \mathrm{~km}$. At that time, the West Kalimantan system suffered an electricity deficit of $30 \mathrm{MW}$ with a capable power of 240 MW. Electricity imports from Malaysia are part of the business of West Kalimantan in the context of overcoming blackouts that have long occurred in the West Kalimantan region, especially in the equatorial system in the last two years. In addition, PLN of West Kalimantan is expected to export electricity to Sarawak, Malaysia through the same EHVT network. This electricity import will potentially savings more than 3.5 billion per day. It will also improve cost of production from the previous $\mathrm{Rp} 2,700$ / kWh to Rp1,700 / kWh (Koran Sindo, 2016).

\section{c. Cooperation on Tourism between West Kalimantan-Sarawak State}

One of the results of the 28th prepanel session of the Malaysia-Indonesia (Malindo) Socio-Economic Cooperation between Government of West Kalimantan and Sarawak's Domestic Affairs is the tourism and cultural cooperation. There are a number of issues under discussion such as the "Joint Tourism Development and Promotion", "Joint Notice Board", "Joint Exit Survey", and Tourism/Tourism Activities Notice. In addition, cooperation in ecotourism, museums, culture and arts, history and cultural values, and cooperation in antiques/cultural heritage objects are also elaborated. Both parties agreed to design joint tour packages and tourism information exchange, and to publish standard operating procedures of tourism transport vehicles across national borders (Antara Kalbar, 2012).

Furthermore, for the joint exit survey, it was agreed to be continued on Entikong and Tebedu borders and only involved custom, immigration, quarantine, and security (CIQS) where the results of the survey would be exchanged between the two countries. West Kalimantan and Sarawak also agreed that each city/district in the two regions would notify all invitations related to culture and tourism events. Particularly for ecotourism cooperation, one of the points 
agreed is the cooperation of the regions concerning Batang Ai National Park in Sarawak, Betung Kerihun National Park in West Kalimantan, and Danau Sentarum National Park.

\section{d. Cooperation on Business Sector between West Kalimantan- Sarawak State}

The business forum was held at Mega Mall Ayani Pontianak, April 2018 in order to strengthen business relations between Sarawak and West Kalimantan. This is the second time of business forum held in Pontianak between the two parties. The first event was held in 2011, where it had been seven years of collaboration. This exhibition is a followup of the memorandum of understanding between Sarawak Business Federation (SBF) and Indonesian Chamber of Commerce and Industry (KADIN) in September 2017 (Kilas Kalbar, 2018).

The business mission is to open opportunities for the private sector to be promoted in both countries, Malaysia and Indonesia. In addition to the business sector, SBF also exhibits a service sector specifically related to health services. Cooperation between Sarawak-West Kalimantan manifests in both parties introducing each superior product in exploring the potential of the two regions. This SBF and Kadin collaboration also addresses the challenges of doing business.

The obstacles faced by entrepreneurs will then be conveyed to the government of both parties. Among
West Kalimantan products that have been marketed to neighboring countries are processed foods. In addition, product skills such as weaving are also promoted (Kilas Kalbar, 2018).

Based on above explanation, West Kalimantan have received huge foreign investments and have collaborated intensively with the closest neighbour State of Sarawak, Malaysia. West Kalimantan have attracted many foreign investments in various sectors especially on energy. While cooperation with State of Sarawak was seen more deeper than expectation. Nevertheless, there still some issues pertaining "controvercial overseas trips" among local government apparatus. Like in Riau Island, local apparatus also under strong criticism due to overseas trip for "budget cleaning" ahead of end of year budget. For instance, Deputy local house in West Kalimantan said that:-

"Kita sudah mendengar selentingan dari masyarakat, mereka bertanya-tanya kenapa disaat anggaran defisit, masih saja mau melaksanakan perjalanan dinas ke luar negeri. Seolah-olah mau jalan-jalan saja [We have heard rumors from the public, they wonder why when the budget deficit, they still want to carry out official trips abroad. Their trip is just for fun]. (Netizen Media, 2018).

This also a strong indication that even in the region which statistically high reputation on paradiplomacy, still have problems with ceremonial paradiplomacy. Public still questioning about the local government apparatus attitudes that tend 
to spend a lot of money for overseas trip amid of local financial difficulties.

\section{Conclusion}

Paradiplomacy in the frontier areas in Indonesia especially in Riau Island and West Kalimantan has been relatively sucessful. This can be investigated in the investment achievement of the two regions. In addition, the stakeholders are also varied among local government apparatus, businessman, MNCs, and individuals. Yet, most of the cooperation were conducted by local elites. In contrast to this, people's empowerment is still left behind. The high number of foreign investments in both provinces has significantly influenced the local economic developments. Nevertheless, there was a serious challenge among local apparatus. The "ceremonial paradiplomacy" is still intensively practiced and is usually implemented through "overseas visit" which led to the rise of public controversy.

\section{About the Author}

Ali Maksum is assistant professor in international relations, Universitas Muhammadiyah Yogyakarta. His expertise is in international relations in Southeast Asia especially migration studies.

Surwandono is associate professor in international relations, Universitas Muhammadiyah Yogyakarta. His expertise is in diplomacy and international relations in Islamic perspective.

\section{References}

Antara Kalbar. (2012). Kalbar, Sarawak Gelar Sosek Malindo Ke-28. Antara Kalbar. Retrieved from https://kalbar.antaranews.com/beri ta/304380/kalbar-sarawak-gelarsosek-malindo-ke-28.

Arindapraja, R. (2015). Kerjasama Sosial Ekonomi Provinsi Kalimantan Barat (Indonesia) dengan Negeri Sarawak (Malaysia). Thesis. Universitas Muhammadiyah Yogyakarta.

Arjuna, D. (2016). Kerjasama Ekonomi Indonesia-Singapura Dalam Realisasi Special Economic Zone (SEZ) di Batam, Bintan dan Karimun. Jurnal Online Mahasiswa Fakultas Ilmu Sosial dan Ilmu Politik Universitas Riau, 3(2), 1-11.

BKPM. (2017). SIARAN PERS: BKPM Luncurkan Perluasan Implementasi KLIK di 5 Kawasan Industri di Provinsi Keppri. Retrieved from https://studylibid.com/doc/680836/ siaran-pers-bkpm-luncurkanperluasan-implementasi-klik-di-5.

Damayanti, C. (2012). Potensi Paradiplomasi Dalam Mendukung Kinerja Diplomasi Indonesia Menuju Komunitas ASEAN. Transformasi, 14(22), 1-9.

Detiktravel.com. (2016). Pak Kasih Tayan, Jembatan Baru Terpanjang di Kalimantan. Detiktravel.com. Retrieved from https://travel.detik.com/domesticdestination/d-3176852/pak-kasih- 
tayan-jembatan-baru-terpanjang-

di-kalimantan.

Fathun, L. M. (2016). Paradiplomasi Menuju Kota Dunia: Studi Kasus Pemerintah Kota Makassar. Indonesian Perspective, 1(1), 75-94.

Harefa, A. O. \& Badaruddin, M. (2016). Posisi Indonesia Pada Kerja Sama Energi Regional Dalam Memasuki Era Masyarakat Ekonomi ASEAN Studi Kasus: ASEAN Power Grid. Paper presented at the Seminar Nasional INDOCOMPAC Universitas Bakrie. Retrieved from https://media.neliti.com/media/pu blications/171809-ID-posisiindonesia-pada-kerja-samaenergi.pdf

Kilas Kalbar. (2018). Business Mission to Pontianak, Kerjasama Bisnis Sarawak-Kalbar. Kilas Kalbar. Retrieved from https://kilaskalbar.com/bisnis/22/0 4/2018/business-mission-topontianak-kerjasama-bisnissarawak-kalbar/.

Koran Sindo. (2016). Bangun Interkoneksi Listrik Kalbar-Serawak. Koran Sindo. Retrieved from http://koransindo.com/page/news/2016-0122/0/4/Bangun Interkoneksi Listri k Kalbar Serawak.

Litsareva, E. (2017). Success Factors of Asia-Pacific Fast-Developing Regions' Technological Innovation Development and Economic Growth. International Journal of
Innovation Studies, 1(1), 72-88. doi: 10.3724/SP.J.1440.101006.

Metronews.com. (2017). Nilai Investasi Karimun Capai Rp16,86 Triliun di 2016. Metronews.com. Retrieved from

http://ekonomi.metrotvnews.com/ mikro/zNAG45zk-nilai-investasikarimun-capai-rp16-86-triliun-di2016.

Ministry of Foreign Affairs. (2016). Interkoneksi Tenaga Listrik Kalimantan Barat-Sarawak Telah Beroperasi [The electricity interconnection between West Kalimantan-Sarawak Fully Operated]. Available in https://www.kemlu.go.id/id/berita/ berita-

perwakilan/Pages/Interkoneksi\%20 Tenaga\%20Listrik\%20Kalimantan \%20Barat-

Sarawak\%20Telah\%20Beroperasi.a spx.

Ministry of Industry. 2016. Laporan Kinerja Perindustrian [Industrial Achivement Report]. Jakarta: Ministry of Industry.

Mukti, T. A. (2013). Paradiplomacy: Kerjasama Luar Negeri Oleh PEMDA di Indonesia. Yogyakarta: The Phinisi Press.

Netizen Media. (2018). Perjalanan Dinas DPRD Kalbar ke Luar Negeri Dibatalkan, official trips cancelled by local house. Netizen Media. Retrieved from http://netizen.media/2018/09/11/pe 
rjalanan-dinas-dprd-kalbar-ke-

luar-negeri-dibatalkan/.

Ngoc, H. L. (2015). Innovation and Economic Growth in Malaysia, Master Thesis. Lund, Sweden: University of Lund.

Pontianak Post. (2016). ANTAM dan ICA Tingkatkan Mutu Kader Posyandu. Pontianak Post. Retrieved from https://www.pontianakpost.co.id/a ntam-dan-ica-tingkatkan-mutukader-posyandu.

PT. Indonesia Chemical Alumina. 2014. Tentang Kami [About Us. Available ini http://www.ptica.com/tentang-kami/?lang=id .

PT. Wilmar International Limited. 2018. Corporate Profile. Available in https://www.wilmarinternational.com/aboutus/corporate-profile

PT. Wilmar International Limited. (2018). http://www.wilmarinternational.com/.

Rofik. (2018). Investasi ke Bintan Sepanjang 2017 Mencapai Rp14 Triliun. Sindonews. Retrieved from https://ekbis.sindonews.com/read/ 1274509/34/investasi-ke-bintansepanjang-2017-mencapai-rp14triliun-1516197949.

Showa Denko. About Us. (2018). Available in

http://www.sdk.co.jp/english/abou t.html
Sinambela, H. K. (2017). Membangun Keamanan Energi ASEAN Melalui Integrasi Listrik Regional (Implementasi ASEAN Power Grid) di Kalbar-Sarawak. eJournal Ilmu Hubungan Internasional, 5(1), 89-102.

Siska. (2018). Awal 2018, PT Hong Sheng Plastic Industry Jadi Investor Pertama Masuk Batam. Swarakepri. Retrieved from http://swarakepri.com/awal-2018pt-hong-sheng-plastic-industryjadi-investor-pertama-masukbatam/.

Tanjung Pinang Pos. (2011). Pejabat KEPRI Merajuk Tak Bisa Ke Luar Negeri, officials sulky on overseas trips cancellations. Tanjung Pinang Pos. Retrieved from http://www.tanjungpinangpos.co.i d/pejabat-kepri-merajuk-tak-bisake-luar-negeri/.

Tavares, R. (2016). Paradiplomacy: cities and states as global players. New York: Oxford University Press.

The Tanjungpura Times. (2016). Investor Asing Lebih Dominan Mengisi Industri Pertambangan di Kalbar. The Tanjungpura Times. Retrieved from

http://thetanjungpuratimes.com/20 16/11/14/investor-asing-lebihdominan-mengisi-industripertambangan-di-kalbar/.

Tobirin. (2013). Formalities and political symbolism of community empowerment in villages' poverty 
alleviation. Masyarakat, Kebudayaan dan Politik, 26(4), 265-275.

Tribun Batam. (2012). Silakan Saja Gubernur ke Luar Negeri Demi FTZ, let governor go abroad for FTZ program. Tribun Batam. Retrieved from http://batam.tribunnews.com/2012/ 11/12/silakan-saja-gubernur-keluar-negeri-demi-ftz.

Tribun Ketapang. (2017). PT WHW AR Ketapang, Ujung Tombak Perusahaan Asing di Indonesia. Tribun Ketapang. Retrieved from http://pontianak.tribunnews.com/2 017/11/13/pt-whw-ar-ketapangujung-tombak-perusahaan-asingdi-indonesia.

Tribun Pontianak. (2016). Investasi Asing di Kalbar Masuk 10 Besar. Tribun Pontianak. Retrieved from http://pontianak.tribunnews.com/2 016/01/24/investasi-asing-dikalbar-masuk-10-besar.

Viodeogo, Y. (2018). Ekspor Kalbar Mei 2018 Naik 22,52\%. Kalimantan Bisnis. Retrieved from http://kalimantan.bisnis.com/read/ 20180703/407/812457/eksporkalbar-mei-2018-naik-2252.

West Kalimantan Provincial Government. 2016. Laporan Standar Pelayanan Minimal Provinsi Kalimantan Barat [Minimum Service Standar Report of West Kalimantan Province]. Pontianak: Biro Organisasi Sekretariat Daerah, Provinsi Kalimantan Barat. 